\title{
The Application of Problem Based Learning Model To Increase Students Achievement In Indonesian Subject
}

\author{
Mareta Nugraha Putri \\ SD Negeri 1 Keden Pedan \\ mareta86cherish@gmail.com
}

Article History

received $3 / 12 / 2020$

revised $17 / 12 / 2020$

accepted $31 / 12 / 2020$

\begin{abstract}
The aim of this study was to increase the third grade elementary students learning achievement on Indonesian subject by applying Problem Based Learning (PBL) model. The research done was a Classroom Action Research (CAR) that had been done in two cycles which each cycle consisted of one meeting. The steps of each cycle were planning, applying, observing and reflecting. Each meeting had evaluation test to determine students learning achievement. On the fist cycle, there were $60.86 \%$ student had completed their study. In the second cycle, there were 95,65\% students had completed their study. This results showed that Problem Based Learning (PBL) model can increase students learning achievement especially in Indonesian subjects of the third grade SD Negeri 1 Keden Pedan.
\end{abstract}

Keywords: problem based learning, learning achievement, Indonesian

\begin{abstract}
Abstrak
Tujuan dari penelitian ini adalah meningkatkan hasil belajar pada pembelajaran bahasa Indonesia di Sekolah Dasar kelas III dengan menerapkan model pembelajaran Problem Based Learning (PBL). Penelitian yang dilakukan adalah Penelitian Tindakan Kelas (PTK) sebanyak dua siklus, dengan setiap siklusnya terdiri dari 1 pertemuan. Tahapan setiap siklusnya adalah perencanaan, pelaksanaan, observasi, dan refleksi. Setiap pertemuan diadakan evaluasi untuk mengetahui perkembangan hasil belajarnya. Pada siklus 1 , siswa yang tuntas setelah evaluasi sebanyak 60,86 \%. Pada siklus 2, siswa yang tuntas setelah evaluasi sebanyak 95,65\%. Hasil ini menunjukkan bahwa model pembelajaran Problem Based Learning (PBL) dapat meningkatkan hasil belajar siswa khususnya pembelajaran bahasa Indonesia kelas III di SD Negeri 1 Keden Pedan.
\end{abstract}

Kata kunci: problem based learning (pbl), hasil belajar, Bahasa Indonesia

Social, Humanities, and Education Studies (SHEs): Conference Series https://jurnal.uns.ac.id/shes

p-ISSN 2620-9284

e-ISSN 2620-9292 


\section{PENDAHULUAN}

Pendidikan merupakan pengalaman belajar baik dalam bentuk formal, non formal, informal, disekolah maupun diluar sekolah. Pendidikan memberi dan membentuk pengetahuan baik secara kognitif, afektif dan psikomotor yang didapatnya melalui pembelajaran yang diajarkan. Menurut Brubacher (dalam Ahmadi, 2014:33) pendidikan adalah suatu proses timbal balik dari setiap pribadi manusia dalam penyesuaian dirinya dengan alam, teman dan alam semesta. Menurut Danim (dalam Ahmadi, 2014:45) tujuan utama pendidikan adalah transmisi pengetahuan atau proses membangun manusia menjadi berpendidikan. Transfer pengetahuan yang diperoleh dibangku sekolah atau lembaga pelatihan ke dunia nyata adalah sesuatu yang terjadi secara alami sebagai konsekuensi dari kepemilikan pengetahuan siswa. Pengetahuan tersebut didapat melalui pembelajaran yang diajarkan oleh guru.

Pembelajaran sendiri merupakan kegiatan belajar mengajar, dimana melibatkan guru sebagai pihak yang mengajar dan bertanggung jawab terhadap pelaksanaan pendidikan siswa sedangkan siswa sebagai seseorang yang ingin belajar atau penerima ajaran baik secara kognitif, afektif dan psikomotor. Di dalam lampiran Permendikbud 2013 No. 81A tentang Implementasi Kurikulum Pedoman Umum Pembelajaran dijelaskan bahwa pembelajaran merupakan proses pendidikan yang memberikan kesempatan kepada siswa untuk mengembangkan potensi dalam hal sikap, pengetahuan dan keterampilannya. Pembelajaran harus diarahkan untuk memfasilitasi pencapaian kompetensi yang telah dirancang dalam kurikulum agar setiap siswa mampu menjadi pembelajar mandiri sepanjang hayat

Saat ini masih banyak proses pembelajaran yang berpusat pada guru (teachercenter). Pembelajaran yang demikian lebih mementingkan hasil daripada proses pembelajaran itu sendiri, sehingga pembelajaran terkesan monoton. Yang menjadi permasalahan adalah ketika dalam menyampaikan materi dikelas, guru selalu menerapkan metode pembelajaran yang monoton, tidak bervariasi dan menjadi kebiasaan sehingga, dapat membuat siswa kesulitan dalam memahami materi yang disampaikan. Oleh karena itu proses pembelajaran yang masih berpusat pada guru seharusnya diubah menjadi proses pembelajaran yang berpusat pada siswa. Persoalan hasil belajar di kelas III SDN 1 Keden mengalami masalah. Hal itu berdasarkan ulangan harian pada siswa yang hanya 50, padahal KKM yang ditentukan sekolah adalah 70 untuk muatan pembelajaran bahasa Indonesia. Dari 23 siswa hanya ada 14 anak yang lulus KKM sedangkan 9 lainnya tidak mencapai KKM

Berdasarkan kurikulum 2013, guru dituntut untuk menguasai berbagai model pembelajaran dengan pendekatan saintifik. Salah satu model pembelajaran dengan pendekatan saintifik adalah model Problem Based Learning (PBL). Model pembelajaran ini memberikan kesempatan penuh bagi siswa untuk aktif mencari dan menemukan pengetahuan yang dimilikinya. Model pembelajaran Problem Based Learning (PBL) menjadikan siswa sebagai pusat pembelajaran dan menekankan belajar secara kooperatif. Untuk pembelajaran ini guru berperan sebagai fasilitator yang memfasilitasi siswa dalam pembelajaran, agar siswa aktif dalam menyelesaikan masalah. Ketika siswa berperan aktif dalam proses pembelajaran dengan bertanya dan menanggapi materi yang disampaikan guru, maka pemahaman siswa menjadi tinggi yang berdampak pada hasil belajar menjadi meningkat.

Tahapan model Problem Based Learning menurut Handayana, (2014: 212) terdiri dari lima tahapan dalam perlakuan guru yaitu: (1) fase 1: orientasi siswa pada masalah, (2) fase 2: mengorganisasi siswa untuk belajar, (3)fase 3: membimbing penyelidikan individual maupun kelompok (4) fase 4: mengembangkan dan menyajikan hasil karya, (5)fase 5 : menganalisis mengevaluasi proses pemecahan masalah. Dengan cara belajar seperti itu, maka akan memberikan pengalaman belajar yang bermakna bagi siswa. Melalui proses pemecahan masalah siswa akan mengetahui situasi dimana konsep materi diterapkan. Tujuan model Problem Based Learning menurut Suprijono (2016:204) adalah mengembangkan keterampilan siswa untuk belajar secara mandiri, 
mengembangkan keterampilan meneliti, dan kemampuan memecahkan masalah, serta membentuk perilaku dan ketrampilan sosial.

Hasil belajar menurut Nawawi (dalam Susanto, 2013:5) diartikan sebagai tingkat keberhasilan siswa dalam mempelajari materi pelajaran disekolah yang dinyatakan dalan skor yang diperoleh dari hasil tes mengenal materi pelajaran tertentu. Menurut Arikunto (dalam Widoyoko, 2016:10) guru maupun pendidik lainnya perlu mengadakan penilaian terhadap hasil belajar siswa karena dalam dunia pendidikan khususnya dunia pendidikan persekolahan, penilaian hasil belajar mempunyai makna yang penting, baik bagi siswa, maupun sekolah. Menurut Rusmono (2012:10), hasil belajar adalah perubahan perilaku individu yang meliputi ranah kognitif, afektif dan psikomotorik. Perubahan perilaku tersebut diperoleh setelah siswa menyelesaikan program pembelajarannya melalui interaksi dengan berbagai sumber belajar dilingkungan sekolah.

Berdasarkan paparan dan pernyataan diatas apakah model pembelajaran Problem Based Learning dapat meningkatkan hasil belajar siswa? Tujuan penelitian ini adalah untuk mengetahui pemecahan masalah belajar yang dilakukan dengan menerapkan model pembelajaran Problem Based Learning pada siswa kelas III SDN 1 Keden.

\section{METODE}

Penelitian ini adalah penelitian tindakan kelas (Classroom Action Research) dengan menerapkan model pembelajaran Problem Based Learning (PBL). Menurut Kurt Lewin dalam Kunandar (2011:42) penelitian tindakan kelas ini terdiri dari empat tahapan dasar yaitu perencanaan (planning), pelaksanaan (acting), pengamatan (observing) dan refleksi (reflecting). Analisis penelitian ini adalah analisis deskriptif kuantitatif kualitatif dimana dalam penelitian ini selain menyajikan hasil berupa data maupun angka, peneliti juga menentukan bagaimana cara pengolahan hasil penelitian yakni dengan membuat analisisnya dengan menerapkan pembelajaran Problem Based Learning (PBL). Penelitian ini dilaksanakan pada siswa kelas III SD Negeri 1 KedenTahun Pelajaran 2019/2020 selama 2 siklus secara luring dengan satu pertemuan setiap siklusnya. Siklus II dilaksanakan 21 Januari 2020 Siklus II dilaksanakan pada tanggal 22 Januari 2020 Teknik pengumpulan datanya dengan tes tertulis.

\section{HASIL DAN PEMBAHASAN}

Setelah menerapkan model pembelajaran Problem Based Learning (PBL) pada siswa kelas III, hasil belajar tiap siklus digambarkan pada tabel dibawah ini.

Tabel 1. Hasil belajar Siklus I dan Siklus II

\begin{tabular}{lcc}
\hline \multicolumn{1}{c}{ Hasil Belajar } & Siklus I & Siklus II \\
\hline Nilai tertinggi & 85 & 100 \\
Nilai terendah & 50 & 68 \\
Rata-rata kelas & 68.13 & 83.35 \\
Jumlah siswa tuntas & 14 & 22 \\
Jumlah siswa tidak tuntas & 9 & 1 \\
Persentase Ketuntasan & $60.86 \%$ & $95.65 \%$ \\
Persentase Ketidaktuntasan & $39.13 \%$ & $4.35 \%$ \\
\hline
\end{tabular}

Berdasarkan Tabel 1 dapat terlihat bahwa terdapat peningkatan rata-rata hasil belajar siklus I dan siklus II. Pada siklus I nilai rata-rata hanya mencapai 68.13 hal ini dibawah kriteria ketuntasan minimal (KKM) yang telah ditentukan SD N 1 Keden yaitu 70. Kemudian dilaksanakannya penelitian tindakan kelas dengan penerapan model pembelajaran Problem Based Learning pada Siklus II yang menunjukkan peningkatan hasil belajar siswa menjadi 83.35, hal ini sudah mencapai indikator capaian penelitian yaitu, 70.

Adanya peningkatan rata-rata hasil belajar siswa juga didukung dengan adanya peningkatan jumlah siswa yang mengalami ketuntasan hasil belajar. Dari 23 siswa pada 
siklus I yang mengalami ketuntasan berjumlah 14 dengan presentase $60.86 \%$ kemudian pada siklus II jumlah siswa yang mengalami ketuntasan hasil belajar meningkat menjadi 22 siswa dengan presentase $95.65 \%$

Pembahasan

Dari penelitian yang telah dilakukan peneliti bersama guru observer dengan penerapan model pembelajaran Problem Based Learning (PBL), terlihat bahwa pembelajaran tersebut mempunyai beberapa kelebihan dan kekurangan. Menurut Putra (2013:82-83) model pembelajaran Problem Based Learning (PBL) memiliki beberapa kelebihan yaitu: (1) siswa lebih memahami konsep yang diajarkan lantaran mereka yang menemukan konsep tersebut, (2) melibatkan siswa secara aktif dalam memecahkan masalah dan menuntut keterampilan berfikir siswa yang lebih tinggi, (3) pengetahuan tertanam berdasarkan skemata yang dimiliki oleh siswa, sehingga pembelajaran lebih bermakna, (4) siswa dapat merasakan manfaat pembelajaran, karena masalah-masalah yang diselesaikan langsung dikaitkan dengan kehidupan nyata. Hal ini bisa meningkatkan motivasi dan ketertarikan siswa terhadap bahan yang dipelajarinya, (5) menjadikan siswa lebih mandiri dan dewasa, mampu menerima aspirasi dan pendapat orang lain, serta menanamkan sikap sosial yang positif dengan siswa lainnya, (6) pengondisian siswa terhadap kelompok yang saling berinteraksi terhadap pembelajaran dan temannya, pencapaian ketuntasan belajar siswa dapat diharapkan, (7) model Problem Based Learning (PBL) diyakini pula dapat menumbuh kembangkan kemampuan kreatifitas siswa, baik secara individual maupun kelompok, karena hampir disetiap langkah menuntut adanya keaktifan siswa. Sedangkan kelemahan model Problem Based Learning (PBL) menurut Sanjaya (dalam Rusmono 2012:219) yaitu : (1) sulitnya mencari masalah yang relevan, (2) persiapan untuk mencapai keberhasilan membutuhkan waktu lama, (3) jika siswa tidak memiliki minat atau kepercayaan dalam memecahkan masalah yang dihadapi, maka mereka akan malas mencoba.

Penelitian Tindakan Kelas dengan model pembelajaran Problem Based Learning (PBL) ini sesuai dengan teori belajar konstruktivisme. Pembelajaran Problem Based Learning mendorong siswa mengkonstruksi pengetahuannya sendiri melalui permasalahan nyata yang membutuhkan suatu pemecahan masalah. Dari beberapa teori konstruktivisme yang paling sesuai dari proses pembelajaran ini adalah teori konstruktivisme menurut Vygostski, sebab ketika siswa terlibat dalam kegiatan diskusi yang dilaksanakan tiap siklusnya, mereka saling bertukar pendapat dan informasi, sehingga konsep materi tersebut dapat ditemukan siswa. Konstruktivisme Vygotski memandang bahwa pengetahuan dikonstruksi secara kolaboratif antar individual dan keadaan tersebut dapat disesuaikan oleh setiap individu. Ini berarti bahwa konstruktivesme Vygostski lebih menekankan pada penerapan teknik saling tukar pendapat, informasi dan gagasan antar individu dalam kegiatan kelompok sehingga siswa dapat menemukan konsep secara mandiri, seperti halnya yang dilakukan siswa kelas III pada kegiatan diskusi.

Dari hasil tindakan pengamatan dan pembahasan dapat ditarik kesimpulan bahwa penerapan model pembelajaran Problem Based Learning (PBL) dapat meningkatkan hasil belajar siswa pada pembelajaran tematik Kelas III SD Negeri 1 Keden tahun ajaran 2019/2020

\section{SIMPULAN}

Merujuk pada hasil penelitian yang telah dilakukan, dapat disimpulkan bahwa penerapan model Problem Based Learning (PBL) pada pembelajaran materi bahasa Indonesia dapat meningkatkan hasil belajar siswa kelas III SD Negeri 1 Keden tahun Ajaran 2019/2020 yang dibuktikan dengan peningkatan hasil belajar siswa dilihat dari peningkatan nilai rata-rata dan peningkatan persentase ketuntasan klasikal hasil belajar. Nilai rata-rata hasil belajar siswa pada penelitian siklus I sebesar 68.13 meningkat menjadi 83.35 pada siklus II dari keseluruhan siswa kelas III yaitu 23 siswa 
DAFTAR PUSTAKA

Ahmadi, Rulam. 2014. Pengantar Pendidikan Asas \& Filsafat Pendidikan. Yogyakarta: Ar-Ruzz Media

Depdikbud. 2013. Permendikbud 81A. Jakarta: Kementrian Pendidikan dan Kebudayaan.

Hamdayama, Jumanta. 2014. Model dan Metode Pembelajaran Kreatif Berkarakter. Jakarta: Ghalia Indonesia

Kunandar. 2011. Langkah Mudah Penelitian Tindakan Kelas sebagai Pengembangan Profesi Guru. Jakarta: Raja Grafindo Persada.

Putra, Nusa. 2013. Penelitian Kualitatif Ips. Bandung: PT Remaja Rosdakarya

Rusmono. 2012. Strategi Pembelajaran dengan Problem Based Learning itu Perlu untuk Meningkatkan Profesionalisme Guru. Bogor. Ghalia Indonesia.

Suprijono, Agus. 2016. Model-Model Pembelajaran Emansipatoris. Yogyakarta: Pustaka Pelajar.

Susanto, Ahmad. 2013. Teori Belajar Dan Pembelajaran Di Sekolah Dasar. Jakarta: Kencana Prenada Media Group.

Widoyoko, Eko Putro. 2014. Penilaian Hasil Pembelajaran Di Sekolah. Yogyakarta. Pustaka Pelajar. 